\title{
Micro Finance in Ghana. Due Diligence on Micro Financial System Management Towards Reduction in Poverty and Unemployment
}

\author{
David Kwasi Mensah \\ Dept. of Accounting \& Finance, Pentecost University Graduate School-Ghana \\ P.O.BOX K1739, KANESHIE, Accra-Ghana \\ Tel: 233-242-68-3751/233-503-770-714Ｅ-mail:kddmensah@gmail.com
}

Dr. V. Rengarajan (Corresponding author)

Senior Consultant at Madras Institute of Development studies, Pondichery University

Kanchipuran, Tamil Nadu, India

Tel: 984-022-3459Ｅ-mail: renga42@gmail.com

Received: January 15, 2019 Accepted: February 23, 2019 Published: February 26, 2019

doi: 10.5296/jsss.v6i2.14427ＵRL: https://doi.org/10.5296/jsss.v6i2.14427

\begin{abstract}
The objective of the paper is to investigate the complexities that are prevailing in the micro financial system which has recently witnessed foray of digitalization and conceivably suggesting an integrated financial product system biased to demand side as a way forward for policy consideration towards mitigating poverty and unemployment in Ghana. For the said purposes, the study is based on secondary data and published official documents. Further, the filed observations of the principle author who has worked as a branch manager in Ghana have been taken cognizance of the empirical facts while doing in both descriptive analysis and drawing conclusion as well.

The major bottlenecks that hinder smooth function of microfinance, include insufficient donor funds to MFIs, lack of proper adherence of rules and regulations improper monitoring system, loan delinquency in the supply side, and continued dependence on traditional money lender regardless of rate of interest poor clients protection and capability differential among
\end{abstract}


the poor clients of MFI in the demand side. For challenging these hurdles, a slew of suggestions which are made for policy considerations include arranging adequate investable fund through institutional linkages, candid identification of target group based on their capabilities as poor, poorer, poorest, designing integrated pro poor financial products and services (credit plus)capability building of the poor through financial and digital literacy and skill up graduation, client protection to the poor till graduation above poverty line, moral suasion to the actors for eschewing higher interest of rate microfinance.

The study confirms the presence of challenges and bottlenecks in the MFI management and the need for due diligence for achieving their mission in terms of reduction of poverty and unemployment.

Keywords: Micro finance institutions, Ghana micro finance institution network, Micro finance, Bottlenecks, Institutional linkages, Integrated products, Client protection, Ghana

\section{Introduction}

Ghana, a country with a population of about 30 million people (2018) but united under one umbrella, with the slogan 'one nation, one people with a common destiny'. Accra is the capital of Ghana which accommodate almost half of the population. Ghana is regarded as a welfare country that provides healthcare and free education to her citizens. Ghanaians have an open culture, good hospitality and easy to adapt. Football is regarded as their national sport even though they have smaller sportively. Micro finance has been a lifeline for a lot of lower income people .It has been recognized as a valuable financial-service tool for the vulnerable with a strong potential at the base of the pyramid. Micro finance institutions have been established in Ghana with the aim of helping to improve the lives of clients and women in general. Micro finance institutions assist the poor in managing their finance effectively.

\subsection{Problem Focus}

Ghana was the luckiest country, located advantageously to serve as the gateway to the continent of Africa since post-independence era from March 1957. This political freedom brought hope and aspiration towards making rapid development and growth of Africa within few years. By 1965, Ghana's per capital growth was negative and after the over thrown of the first president (Dr Nkrumah) in 1966, conditions had deteriorated. Continued coup de tat in the 1970s made the economic conditions worse .Eventually, by early 1980s, Ghana's per capital Gross Domestic product (GDP) had reached her nadir and macroeconomic performance had become unstable. There was the growing dependence on aid and foreign inflow (www..Cambridge) According to institute of statistical, social and Economic research(ISSER), Ghana in year 2013an average of 4.9\% GDP growth and per capital GDP growth of $2.9 \%$ had been recorded as the best for that period. Economic and political liberalization in the 1980s and 1990s saw the miraculous decent growth performance. Since the promise of democracy combined with economic and social development in 2000s, the macroeconomic policy has improved dramatically and policy reversals and deviations from the planned approach have been reduced to a minimum level. But the correlation between economic growth and social impact on poverty do not tally. The prudential perception is that 
the number of people living below the poverty line and the level of unemployment have not much changed. A survey conducted by Ghana statistical Service in 2013 reveals that 6.7 million Ghanaians are poor accounting $25.44 \%$ to the total population of 26.34 million. In the case of the problem related to unemployment in Ghana, according to Ghana statistical service (GSS), over 1.2 million able body youth from ages 15 years and above which represent $11.9 \%$ of the labour force are jobless (2018).

The prevailing socio economic condition in Ghana indicates that there is an imperative need to rejuvenate justifiably the functioning of micro financial system functioning in both supply and demand side towards challenging the twin problems stated above.

\subsubsection{Supply Side Scenario}

In the supply front, unstable macro-economic conditions coupled with weak corporate governance and risk management in majority of the banks over few years, led to greater level of non-performing Asset (NPA) and misuse of depositors' fund coupled with breach of the regulatory requirement. Lack of enforcement of the banking rules contributed to solvency and liquidity challenges in the financial sector. This had implications on some weak banks and specialize deposit-taking institutions (Savings \& Loans Companies, Finance Houses, Rural and Community banks, and Microfinance Institutions). This poor management of financial institutions led to the collapse of seven banks, and having negative effect on depositors, creditors, employees, suppliers, and other stakeholders. The recovery task from this ugly situation costed the Ghanaian government to the tune of Ghanaian Cedi (GHC) 9.9 billion (Bank of Ghana, 2018).

\subsubsection{Demand Side Situation}

In the demand front, Ghanaian poverty could be portrayed in terms of lack of opportunities, hunger, illiteracy, education, physical and mental hopelessness, and cannot boast for the future. It also involves neglect of economic shortage, political and social exclusiveness, benefiting from social development and not optimistic of the future.

A survey done in 2013 by Ghana Statistical Service (GSC) blows out that 1 out of 12 Ghanaian citizen live in abject poverty. The vulnerable feeds on Ghanaian Cedi (GHC) 2.17 per day and the vulnerable Ghanaians who are found in Agriculture sector. They are mostly found in subsistence farming which has no value for their sustainable livelihood. Beside poverty, unemployment to youth stands formidable challenges to Ghana. Evidently to quote an example, the recruitment of 500 personnel into the Ghana Immigration Service in 2018, where over 15,000 applicants applied highlighted the magnitude of unemployment in the country

\subsection{The Objectives}

As against the socio economic profile of Ghana nation, the twin problems that merit urgent attention are reduction in poverty and unemployment. In this context the role of micro finance and financial management system for challenging the above national issues assume importance. To investigate further on the issues focused above, the paper seeks to probe with 
the following objectives

To critically overview the functioning of MFIs in Ghana and their role in reduction of poverty and unemployment 2. To identify the bottlenecks that hinders the smooth functioning of micro finance in Ghana and 3. To suggest remedial measures as a way forward towards reduction of poverty and unemployment in Ghana

\section{Methodology}

For the said purposes, the study is based on secondary data and published official documents. Further, the filed observations of the principle author who has worked as a branch manager in Ghana have been taken cognizance of empirically while doing in both descriptive analysis and drawing conclusion as well. The paper is organized into three sections. While the first one critically reviews the functioning of the Micro financial system towards reduction in poverty and unemployment, the second section prudently identifies the bottlenecks that hinder the productive functioning of microfinance. Then follows in the last with a slew of suggestions for taking remedial measures for poverty cure through integrated microfinance product and services.

\subsection{Previous Studies}

The earlier studies have shown in general that micro-finance has potential role for challenging the poverty in terms of three broad roles in development: 1) It helps very poor households meet basic needs and protects against their vulnerable living condition, 2) MF integrated with nonfinancial inputs facilitate improvements in household economic welfare in poverty sector and 3) it also facilitates empowerment of women by supporting women's socio economic and political participation leading to gender equity.

Regarding the functioning of Micro Financial Institutions in particular, the issues being faced by them have been reviewed by many studies in different regions. A case study on MFI in Mogadishu, in Somalia, done by Dahir (2015) reveals that the major obstacles experienced by MFIs include supply of limited microfinance products and services to meet the demands of the poor clients and inadequate support from the government and the donor agencies. In the case of Ethiopia, as reported in another study by Hurissa (2011) MFIs faced the challenges like limited outreach, high operating cost, unregulated government and NGO operation.

The characteristic features of micro financial products and services have been analyzed by various researchers. The revealing facts indicate that the micro financial services include micro-credit, savings, micro-insurance, micro-leasing, and money transfer and payment services. Besides these services, includes micro pension also as it is found in India (Rengarajan, 2013). The characteristics that differentiate micro finance from other financial services are; petty loans advanced, savings mobilized, zero asset- based collateral and easy of operations in Nigeria (Lidgerwood et al., 1999). According to another source, Micro finance is classified as a scheme which alleviates the vulnerability of the poor by providing financial services to them and their petty businesses (Leikam, 2012; Aigbokham et al., 2011; Irobi 2008; Morduch, 2002). It is also argued that micro finance creates jobs, multiplies household income, suppresses unforeseen shock and builds future businesses for the poor. 
Although these studies highlighted the diversified functional utilities of microfinance for the poverty sector, the functioning of Micro credit product in particular as a panacea for poverty has become debatable embedded in both positive and negative outlooks. From the positive front according to Simanowitz and Brody (2004), micro-credit is a key strategy in reaching the MDGs and in building global financial systems that meet the needs of the most poor people." Littlefield, Murdoch and Hashemi (2003) stated "micro-credit is a critical contextual factor with strong impact on the achievements of the MDGs. Micro-credit is unique among development interventions: it can deliver social benefits on an ongoing, permanent basis and on a large scale". Sustainable access to microfinance helps alleviate poverty by generating income, creating jobs, allowing children to go to school, enabling families to obtain health care, and empowering people to make the choices that best serve their needs." (Kofi Annan, December 2003).

However, some school of thought remain skeptical on the linkage between micro credit and poverty cure Predominantly, Rengarajan (2013) in his monograph on Microfinance, has critically viewed that micro credit alone is inadequate to address the poverty issue and emphasized that micro credit need to be integrated with other pro poor microfinance components like micro insurance, micro savings and micro pension etc. Further he strongly argues that within the poverty pyramid, there is a need to distinguish the poor into three categories viz., the poor, the poorer, and the poorest and identify the specific needs to each segment at demand varies due to different levels of deprivation and vulnerability .For example the bottom poor in the pyramid may require only welfare goods for immediate survival and capability building and not micro credit first while others in upper layer in the pyramid demand micro credit plus services. On similar vein, Ali Alshebami in his PhD (2017) thesis, has highlighted that MFIs need to introduce the concept of integrated microfinance so that microfinance could usher in a positive outcome in the demand side in terms of enhanced reduction of the potential risk attached with the poor borrowers' business and eventually buoyancy in the standard of living of the poor community. Hulme and Mosley (1996) concluded from their research on micro-credit that "most contemporary schemes are less effective than they might be" (1996). The authors argued that micro-credit is not a panacea for poverty-alleviation and that in some cases the poorest people have been made worse-off.

Contextually the regarding to recovery performances of MFI in Ghana, the MFIs also identified some of the major factors of default/delinquency in MFIs in Ghana to include poor appraisal, lack of monitoring or improper monitoring, improper client selection, diversion of funds on the part of clients, unwillingness of clients to pay, lack of training for the clients, illiteracy and inadequate skills of clients, poor business practices, and macroeconomic factors, poor management styles among others. These factors or causes confirm the findings of the study conducted by Ahmad, (1997), who found that lack of willingness to pay loans coupled with diversion of funds by borrowers, willful negligence and improper appraisal by credit officers are some of the causes of loan default

Johnson P. Asiama (2007) in his study titled 'Microfinance in Ghana -An overview' concludes that in all, the potential economic benefits of sustainable microfinance in Ghana are compelling, and its potential effects on the development process cannot be understated. 


\section{Ml Macrothink}

This calls for a holistic approach, as discussed to facilitate the development of the microfinance sub sector and thereby unleash its potential for accelerated growth and development.

To sum it up, although different products and services are identified beyond micro credit as pro poor services, there is a limited literature pertaining to performance of these multiple products except micro credit, in detail and their impact of microfinance on the different layers in the poverty pyramid in Ghana The research activities about micro finance and micro financial system management at field level in Ghana towards reduction in poverty and unemployment is feeble and inadequate. The studies undertaken are also found uncoordinated. In this regard, there is no national research agenda to inform planning and policy formulation and implementation in the country.

The present paper is believed to initiate to investigate the complexities that are prevailing in the micro financial system and conceivably suggesting an integrated financial product system biased to demand side as a way forward for policy consideration towards mitigating poverty and unemployment in Ghana.

\subsubsection{Functioning of Microfinance in Ghana- An Over View}

An attempt has been made to identify the Microfinance system within the overall financial sector in Ghana. The Ghana financial sector broadly encompasses five categories of financial institutions as illustrated in the following diagram

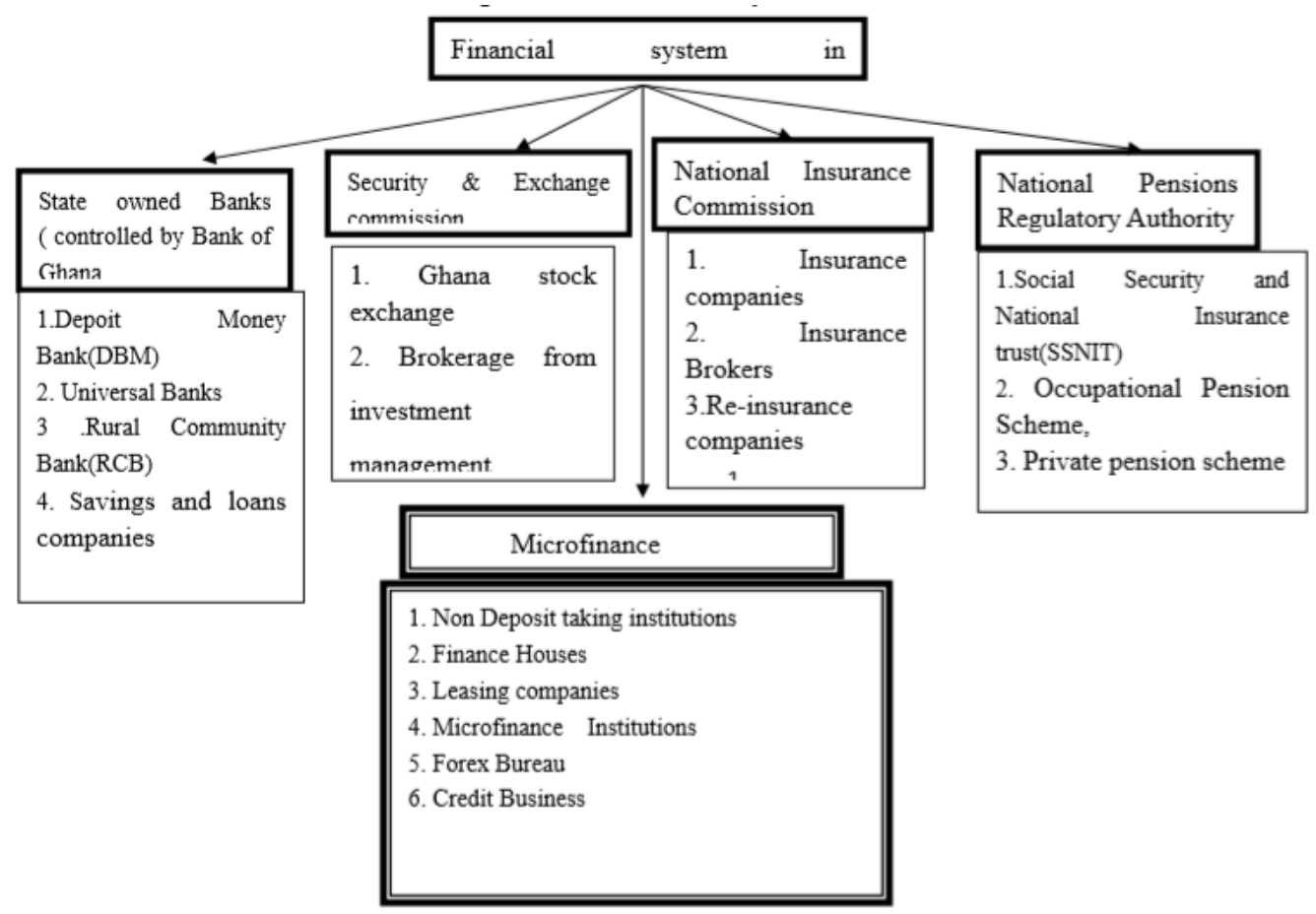

Figure 1. Structure of financial system in Ghana

Source. Compiled by the authors

Figure 1 exemplifies the diversified structure and financial services of the financial institutions that influence the economic growth of Ghana. 


\section{Ml Macrothink}

Journal of Social Science Studies

ISSN 2329-9150

2019, Vol. 6, No. 2

The state owned banks are regulated and supervised by the apex bank, Bank of Ghana. These banks include Deposit Money Banks (DMB), Universal banks (UB), Rural community Banks (RCB), savings and loan companies and Consolidated Bank Ghana Ltd. Financial sector over view (Frankfort school 2010) reveals that the majority assists accounting $85 \%$ of total assets of these state owned banks, belong to DMB.

Next comes to the Ghana Securities and Exchange Commission (SEC) whose primary concern is to protect investors and maintain the integrity of the securities market. As more and more first-time investors begin to look upon the securities market as an alternative investment opportunity and as a means of securing their futures, paying for homes, and educating children, these goals are more compelling than ever. The world of investing is fascinating, complex, and can be very fruitful. However, it must be borne in mind that shares, bonds and other securities can lose value. There are no guarantees. However SEC gives protection to the investors who put their money into the securities markets by monitoring their investments and asking questions.

National Insurance Commission (NIC) The vision of NIC is to be a model financial services regulator in Ghana. Mission The mission of NIC is "to be an effective custodian of the public interest by ensuring financial soundness of insurance companies and the protection of the interest of policyholders "Core values As part of the new strategic direction of NIC, operations will be guided by our core values. These are: 1. Integrity 2 . Transparency 3 . Accountability 4. Responsiveness 5.Accessibility 6.Innovatio

National Pensions Regulatory Authority. The new National Pension Scheme was instituted by the National Pensions Act, Act 766 which ensures that every Ghanaian worker receives retirement benefits as and when due. The 3 -Tier scheme covers all workers in both the private and public sector. It is optional for the self-employed.

The First Tier is the Basic National Social Security Scheme for all workers in Ghana. It is a defined benefit scheme and mandatory for workers to have $13.5 \%$ contributions made on their behalf. The contribution is managed by SSNIT.

The Second Tier is a defined contributory Occupational Pension Scheme mandatory for workers with $5 \%$ contribution made on behalf of members. The contribution is managed privately by approved Trustees.

The Third Tier which includes all Provident Funds and all other Pension Funds outside Tiers I and II is a voluntary scheme.

Microfinance institutions. The concept of microfinance is not new in Ghana (Johnson, 2007). There has always been the tradition of people saving and/or taking small loans from individuals and groups within the context of self-help to start businesses or farming ventures. For example, available evidence suggests that the first credit union in Africa was established in Northern Ghana in 1955 by Canadian Catholic missionaries. However, Susu, which is one of the traditional popular microfinance schemes of the poor community in the informal sector in Ghana, is thought to have originated from Nigeria and spread to Ghana in the early twentieth century. Over the period, the policies have led to the emergence of many kinds of institutions delivering the microfinance services in both semi-formal and formal sector also recognized by the Government of Ghana and Bank of Ghana which acts as the Apex bank authority. These 
institutions which cater micro financial services could be broadly classified under the three sectors as portrayed in Figure 2.

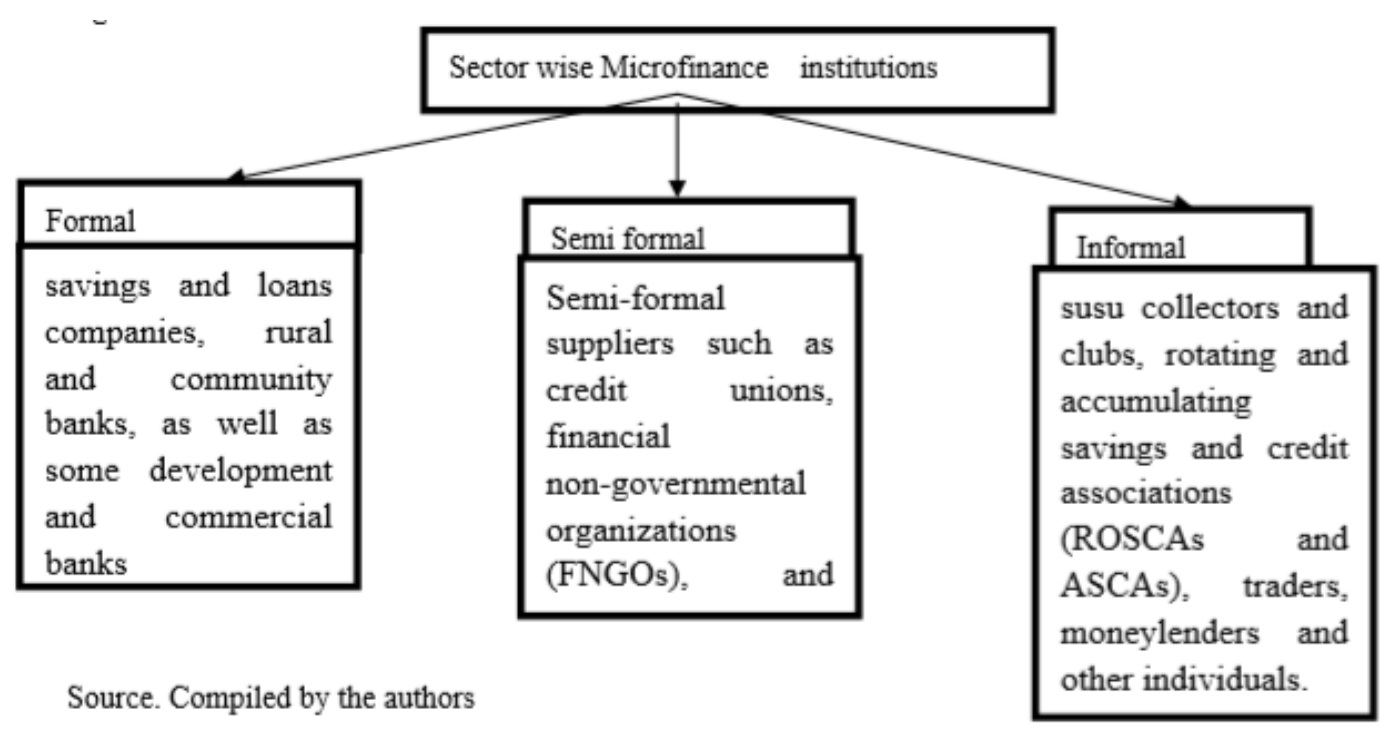

Figure 2. Sector wise Microfinance institutions in Ghana

Figure 2 reveals that microfinance in Ghana is served to the clients by the institutions that are found in the entire three sector there by indicating the participation of public and private institutions together towards uplifting the livelihood of the poor through micro finance support .However each sector has some distinct features (Johnson, 2007) as describes below The formal financial sector in Ghana includes the Traditional Commercial Banks, Rural and Community Banks and other financial institutions such as the Savings and Loans Companies whose operations are registered, licensed and regulated by the Bank of Ghana.

The semi-formal sector comprises of informal institutions that are formally registered but not licensed/regulated by Bank of Ghana such as the Credit Unions of Ghana, Ghana Cooperatives Susu Collectors Association, Ghana Cooperative Council and Association of Financial Non-Governmental Organizations. They constitute the key stakeholders of the Microfinance Sub-sector in Ghana.

Informal financial sector is the components of the financial sector whose service providers are usually not registered and unregulated by the Bank of Ghana and rarely involve legal documentation. The segment includes Money lenders, Susu clubs, Rotating Savings and Credit Associations (ROSCAs). Rotating Savings and credit association (ROSCAs) and Accumulated savings and credit associations (ASCA s) have been existing traditionally in the informal sector representing a candid microfinance which is self managed by the community members themselves. In fact ROSCAs and ASCAs are simple clubs that require participants to make regular contributions into a pool of common funds which are then allotted in rotation to each participants in turn.

\subsubsection{Target Groups}


According to Bank of Ghana, the target groups Microfinance encompasses the provision of financial services and the management of small amounts of fund through a range of products and a system of intermediary functions that are targeted at low income clients. It includes loans, savings, insurance, transfer services and other financial products and services.

\section{Demand for MF}

The demand for MF IN Ghana emerges from four factors. Firstly, the poor need access to productive resources, with financial services being a key resource, if they are to be able to improve their conditions of life; Secondly, the realization that the poor have the capacity to use loans effectively for income-generation, to save and re-pay loans; , the observation that the formal financial sector has provided very little or no services to low-income people, creating a high demand for credit facility_and savings services amongst the poor; the view that microfinance is viable and can become sustainable and achieve full cost recovery; This apart, $\mathrm{tt}$ is also believed that microfinance can have significant impact on cross cutting issues such as women's empowerment, reducing the spread of HIV/AIDS and environmental degradation as well as improving social indicators such as education, housing and health.

The microfinance subsector provides employment opportunities to Ghanaians in rural areas and the extent of employment in various MFIs is presented in Table 1.

Table 1. Number of persons employed in microfinance subsector at the end of December, 2014

\begin{tabular}{lll}
\hline Types of Institutions & No of offices & No. of Persons Employed \\
\hline Savings and Loans institutions & 24 (with 404 branch offices) & 8,591 \\
MFS Institutions & 661 & 9,521 \\
Rural and Community Banks & 143 (with over 651 branches) & 6,465 \\
Credit unions & 555 & 2,516 \\
Financial Non-Governmental organization (FNGO) & 40 & 397 \\
Money lenders & 304 & 1,923 \\
Corporate money lender & 107 & \\
Susu collectors(clubs) & 494 & 1,668 \\
Total & & 31,071 \\
\hline
\end{tabular}

Source: Bank of Ghana.

\section{Market Penetration}

Table 1 reveals the number of offices and their network branches in the last mile which are supported by their good number of employees accounting 31,071 which enabled the market penetration and financial inclusion to a greater extent in the last mile. Among the MFIs, MF companies provide higher level of employment accounting $30.64 \%$ of total employed in MF industry followed by savings and loans institutions with $27.84 \%$ in this regard. Another 


\section{Macrothink}

indicator of market penetration is total asserts, gained by the financial institutions which is presented in Table 2 attached with a graphic representation.

Table 2. Institution wise Market Penetration as on August 2014

\begin{tabular}{llll}
\hline Institutions & No of Reporting & Total Assets (GHSbn) & Share \% \\
\hline Banks & 27 & $46,812.82$ & 85.77 \\
NBFIs & 57 & $5,106.84$ & 9.36 \\
RCB & 137 & $1,886.14$ & 3.46 \\
MFIs & 447 & 772.92 & 1.42 \\
Total & 668 & $54,578.74$ & 100 \\
\hline
\end{tabular}

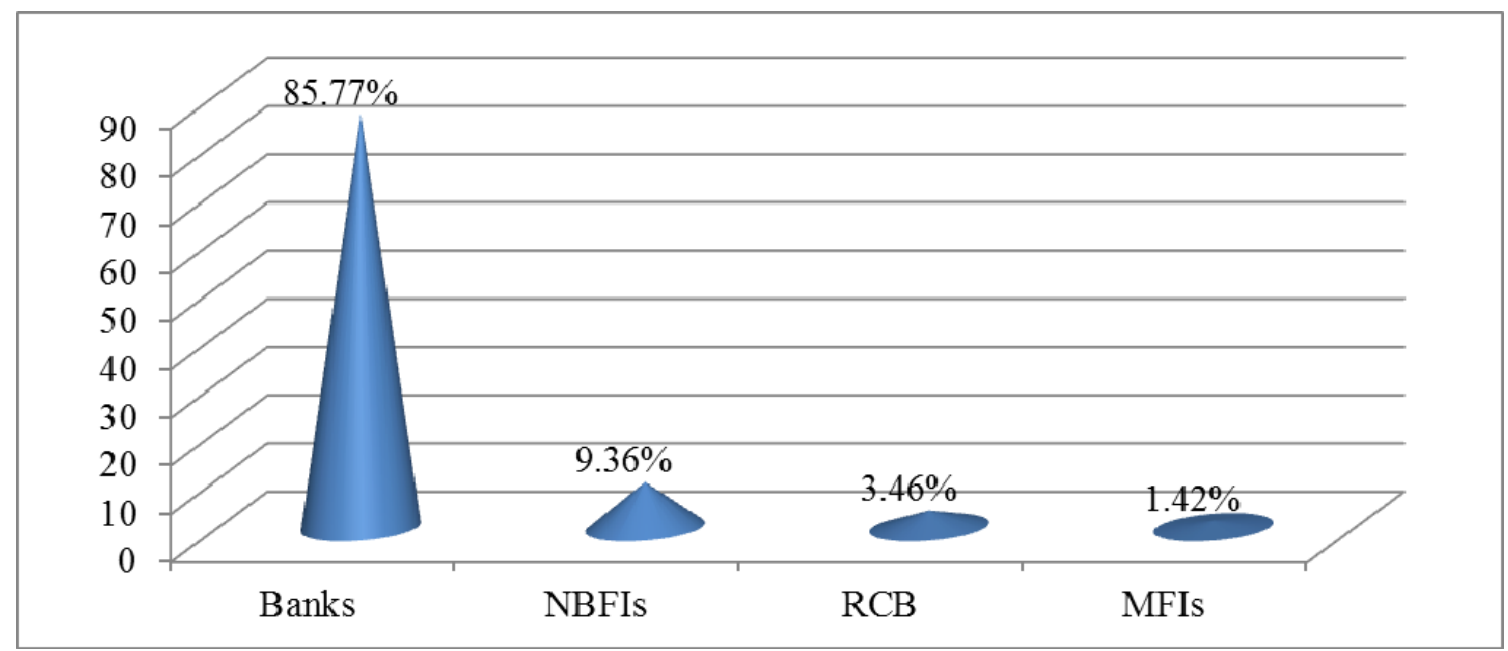

Source: Bank of Ghanayear 2014.

Table 2 indicates that the banks in formal sector having less number of branch networks registering just only $15 \%$ of total number of offices, own a lion's share of assets accounting $86 \%$ of the total assets of finance industry. Where as the share of asset of others representing NBFI, RCB \& MFIs is only $14 \%$ but have $75 \%$ of network of branches demonstrating the extent of their market spread and outreach physically for establishing dyadic relationship with the poor community the last mile

Ghana Microfinance Network (GHAMFIN) (http://www.ghamfin.org/about-ghamfin/)

It is interesting to observe the establishment of an informal network of institutions and individuals that operate within Ghana's Microfinance Industry called GHAMFIN. This Network evolved from the concern of some Ghanaian Microfinance Institutions (MFIs) for the development of reigning best practices in delivery of microfinance services. At the time of incorporation its membership consists of 80 regulated and non-regulated microfinance institutions that together are serving over 60,000 clients. Its members include institutions of different sizes and legal structures such as commercial banks, savings and loan institutions, NGOs, cooperative, rural banks and traditional 'Susu' savings clubs. 
Technical support through capacity building remains the core activity of GHAMFIN. The network creates the opportunities to deliver capacity-building programmes on demand-based services such as training courses, exposure visits and workshops. The capacity building aims at improving MFIs performance and efficiency in promoting inclusive finance.

Capacity-building provided over the years, includes training (areas financial management, information, communication and technology (ICT) development, digital financing and product \& service development) coaching, mentoring and technical assistance for institutional strengthening.

Performance monitoring project and political lobbying is also one of its activities. Establishing a concrete dialogue with the Ghanaian government and external donors which would pave a fortune with the MFIs in Ghana.

\subsection{Products and Services}

.Microfinance institutions innovates pro poor products and services that facilitate the poor community for meeting their financial needs mainly for income generation activities eventually empowering vulnerable Ghanaian able to raise their standard of living. Such products and services are described below,

\subsubsection{Microfinance Product and Services}

Micro credit. A small amount loan is given principally for the purpose of running micro enterprises or any for income generation activities.

Micro savings: The probability of the poor to save money with no minimum balance. It allows everybody to have money for unforeseen use and unexpected expenses.

Micro insurance: It gives the able body entrepreneurs the opportunity to concentrate more on development of their income generating micro enterprises.

Micro leasing: This is for entrepreneurs who are not able to afford the full cost than instead lease equipment, agricultural machinery, or vehicles.

Money Transfer: This service is for transferring money, primary from overseas to family, friends and relatives. Western Union is usually the major international money transfer system for this operation.

Education and support system: building services through financial literacy which include maintenance of book keeping and accounting of financial transactions

Microfinance institutions also provide other kind of financial services such payment service, money transfer, to the vulnerable and low- income households.

\subsubsection{Financial Inclusion Through Microfinance}

Another interesting feature of microfinance, of late, is its role of medium of financial inclusion more particularly in poverty segment. It is a fact that financial inclusion meets the need of the vulnerable population in the country and it does that through micro finance which is the soul of financial inclusion. Financial inclusion targets everybody who has been eliminated from financial service and provides the full range of services they require. Roodman describes microfinance as 'delivering useful financial services to tens of millions of people in a business like way' (providing financial service in a way that helps people moves themselves out of poverty') (Roodman, 2011). Financial inclusion has helped the vulnerable 
population to access the useful financial tools. In the case of Ghana nation, encouragingly with the presence of good network of informal players like Susu clubs, income \& savings institutions, ROSCAS and others like credit unions, FNGO in semi formal sector (Table 2) outnumbering the presence of units of mainstream financial institutions, it is no exaggeration to observe that microfinance institutions has facilitated immensely for financial inclusion of hither to unbanked Ghanaians in rural areas in Ghana

\section{Digitalization in Microfinance Industry}

In the process of growth and development in the earth, digitalization has become inevitable tool Driven by various technology based initiates, taken for financial inclusion, assumingly it is surmised that by the year 2020 an entire generation will have grown up in a primarily digital world through various modes like computers, mobile phones, internet, texting, social networking (Rengarajan, 2018). Globally out of 7.3 billion on the earth over 3 billion can access the internet (ITU 2014). Interestingly digital transformation is dramatically changing micro finance sector in Ghana. Microfinance providers are dealing with server competition and digitization is helping it to introduce new products and services to low-income and unbanked people. As microfinance operators getting used to digital finance, digitization of existing services, products and operation could boast their performance. At the same time the impact of this digital happening in the given demographic characteristics in developing countries need to be prudently watched .According to Rengarajan (2018) the phenomenon of digitalization is reaching an inflection point. The effects of an increasingly digitalized world are now reaching into every corner of human lives with ultimate outcome both in terms of positive and negative implications.

On positive front, the supply side of microfinance has many advantages. In fact digitization has created opportunity to micro finance operators to leverage their license, change their customer base and outreach to rural communities and low-income population. Digital solutions help micro finance institutions to deepen customer engagement and product usage, promote and increase financial inclusion. Digital channels enable microfinance operations gather data faster; determine risk profiles and new customers. The burden of data management in Ghana is set free, as digital data can store, gathered, structure and analyze is more efficiently than traditional base paper method does. This has helped microfinance institutions to lower cost, clients products, eliminate fraud and expand their customer base. On the demand side, digital financial services is convenient to customers, help them to access payment, savings and insurance in their door steps even if they are in the rural areas. It has also minimize risk to the lowest possible and impact in the lives of the vulnerable, and village customers whom might have travelled to a branch which is expensive and time wasting and also need not pocket large sums of cash in their pockets and purse, reducing the risk of the theft. Digital finance has enable customers to do business, premiums in seconds without travelling or close their business and also reduce the hours of microfinance group meetings in Ghana. Moreover, it has allowed Ghanaians with no access to banking to start building transaction history, which enabled them to access loans easier, and also airtime and mobile money activity.

However, negative fallouts of digitalization also emerge simultaneously more particularly in developing countries due to contextual demographic characters more concerned with the 
level of literacy profile. While digital push globally is exciting, its future in any part of the world rests on supporting quality infrastructure in built with risk framework (Rengarajan, 2018) In this regard Micro Save study (Micro save blog, 2016) has brought out the negative fallouts of the digital inclusion in terms of risk involved and occurrence of fraudulent practices across different markets and the players in the financial markets which take the lead in global digitalization. Cyber crime and cyber security enviably are omnipresent as an inexorable component of digitalization. The said fact holds good in Ghanaian context also since adult(15+) literacy rate for Ghana was 76.6\% in 2015 (knoema.com〉 World Data Atlas) indicating nearly one fourth of Ghana's adult may likely to remain excluded in the digitalized financial market and occurrence of digital divide is imminent.

\subsection{Microfinance Crisis in Ghana}

While microfinance sector in Ghana is overviewed, it is not out of place to refer the microfinance crisis experienced in Ghana along with other countries like Nigeria, Bosnia Herzegovina, Nicaragua, Morocco India, and Pakistan. Due to 2011 events germane to global microfinance crisis (Rengarajan, 2013), the microfinance industry suffered a lot and MFIs incurred a huge loss. The main reasons, attributed to MF crisis in Ghana include refusal of repayment of loans by the micro credit borrowers and the micro finance centers and political interference (Rengarajan, 2013). This event has eventually resulted in liquidity crisis for promoting SME sectors. Following other factors that are found both at macro and micro level economy also have fuelled the crisis.

First, most of the MFIs who operate through their network of branches have not cared risk factor and due diligence, at micro level MFI's mismanagement and gross violation of bank of Ghana's rules and regulations. According to Ayeh (2015), some of the microfinance institutions established branches in order to increase their share of the market, but they forgot their overhead cost, and other expenses. Some of them also failed to adopt the core financial intermediation principles. This is not surprising as Bank of Ghana has also raised concern of competence of managers of microfinance institutions in the Ghana.

Second macroeconomic instability also affected microfinance institutions. During the period of crisis and aftermath also, Microfinance institutions in the country were facing great challenges mainly due to their lack of competency and discipline in the unethical financial market environment.

Third, declining economic growth fell from 14\% in 2011 to $3.7 \%$ in 2016 , depreciating of the country's cedi at a faster rate. Eventually, weak banking system and unstable financial system affected severely the microfinance institutions.

All the ecological scenario at macro level, as portrayed above have driven the public to sense a negative perception about microfinance institutions in the country and consequently there were increasing panic withdrawals hitting the most customers (Boateng \& Boateng, 2014). Further, most of the Ghanaians were becoming impatient with microfinance institutions and so they rushed to withdraw their savings and stop transacting business with the institutions. The impact was that majority of the populace became poorer and poorer with businesses collapsing and hope for the future started fading. Poor corporate governance and risk 
management led to high levels of non-performing Asset (NPA) and misused of depositors fund, through related parties much against the Bank of Ghana's regulatory requirements.

In short the overview of functioning of microfinance in Ghana reveals three main observations

- There is a good network of MF offices in formal, semiformal and informal sectors indicating effective market penetration for catering micro financial services in Ghana

- There are diversified Microfinance products and services viz., micro savings, micro credit, micro insurance and micro leasing which are provided in a sequestered manner but there is no integrated MF products that suit the poor holistically

- There is a lack of adherence of rules and regulations of Apex bank (BOG) by MFIs and lack of institutional linkages

- Digitalization in financial sector is too fast to include all without adequate preparedness given demographic feature. Digital divide is imminent.

4.1.1 The Bottlenecks Facing Micro Finance Industry

Micro finance institutions in Ghana are like that of any other MFIs in the globe; Principally poverty segment is MFIs' niche market. The target people in the informal sector are poor challenging daily various kinds of vulnerability and deprivation for eke out their living. These target people with low demographic features like social exclusion low literacy, low income, myths and beliefs, societal values, patriarchal system, are susceptible to changes in the surroundings. This apart, global instability in Microfinance sector, driven by the last MF crisis also influenced the free flow of funds influence the nature of functioning of these MFIs both in supply and demand sides in Microfinance sector. These changes generate bottlenecks and challenges in different wave length in the eco system where MFIs operate resulting in poor performance of them. Ghana is not an exception.

Research studies have asserted the prevalence of such hurdles affecting the smooth growth of MFIs and their mission towards reduction of poverty and unemployment. These hurdles are presented below distinctly under supply and demand side as it would facilitate for taking remedial action appropriately as a way forward in microfinance sector.

In the first, the research department of Bank of Ghana (Johnson, 2007) reveals some of the hurdles being faced in MF sector In Ghana. The summary of such challenges by and large supply side oriented are given below

Supply side

- The microfinance since 1950 has operated without specific policy guidelines and goals that led to haphazard growth without any regulation and supervision.

- As a corollary to the above, there are many constraints which include inappropriate institutional arrangements, poor and regulatory environment, inadequate capacities,

- There is also lack of coordination and collaboration, poor institutional linkages,inadequate skills and professionalism

- Absence of coverage of microfinance sub sector under appropriate regulation. There is a concern on the sustainability of MFIoperation for which appropriate regulation needs to be extended other institutions operating in the microfinance sub-sector ((for example the legal 


\section{Macrothink}

Journal of Social Science Studies

ISSN 2329-9150

2019, Vol. 6, No. 2

framework for credit unions) in order to improve the outreach, sustainability and efficiency of savings, facilitate credit delivery, and institutional arrangements.

\subsubsection{Bottleneck identified by GHAMFIN}

The comments, outlined on the hurdles challenging the MF sector in Ghana by GHAMFIN are presented distinctly those pertaining to supply and demand sides for better appreciation on the magnitude of the problems since these are reflections of the MFI themselves operating in Ghana.

\section{Supply side}

- insufficient donor funds

Firstly, there is insufficient donor funds from the international communities. Ghana is a third world country and very poor in funds management. She therefore at times relies on advance countries for donor support and when they are not forth coming, it becomes very difficult for the microfinance to function properly. Also the government does not support the institutions properly. This is because the Ghanaian government budget and economic policies are over stretched. It therefore makes few percent provisions for the microfinance institutions in her budget statement. Current resources are insufficient to meet all the institutions demand and current population and therefore some institutions are affected and micro finance institution is one of them.

- Lack of proper adherence of Rules \& Regulation

Second, rules and regulations designed by Bank of Ghana (BOG) are not properly followed by the microfinance institutions. GHAMFIN whose responsibilities are to help the growth of microfinance institutions are not able to help in monitoring the rules and regulations of microfinance policies in the industry. This makes it more complex when staffs who are not trained and have not undergone rigorous professional courses in microfinance organized by institute of Chartered Bankers (Ghana) are employed.

- Improper Monitoring/reporting system

Third, there is no proper reporting performance and monitoring systems on microfinance institutions. Microfinance institutions do not have standard software which is used for their data and information and a format which they will use to prepare their financial information to Bank of Ghana. Therefore, other institutions who will like to have their prepared financial statements for assessment faced a lot of challenges which different microfinance institutions having different reporting format.

- Credit risk due to loan delinquency

Lastly, credit risk is a great challenge, since most of the defaulters of loans will damage the system. High interest rate makes most of the loaners to default leading to loan delinquency and mounting Non Performing Asset(NPA). This situation therefore make MFIs to harass the staff and officials who chase the defaulters for loan recovery.

Demand side

- High Cost of funds

Dependence of money lender /Friends \& relatives for funds regardless of interest cost is a major threat to MFI clients. Money lenders give emergency finance to clients who are 
vulnerable and need assistance. They provide loans for urgent cash need for businesses and family needs. They are fast and timely access with no collateral but the cost are high (Adams, 1992) Clients need loans for investment in order to increase their income, have necessary skills to generate income activities, health, education and better future. The results of the studies of Robinson (2001), shows that demand elasticity of interest rate is negative, which proves that the vulnerable do not care about interest rate so long as they get the loan. In the case of small business entrepreneurs borrow money from friends/ relatives who have surplus funds for lending with higher interest rate ranging from 100\% to 200\% (Asiedu-Mante 2001) Authors observations on the hurdles in MF sector

From the past a few decades of exposure in Microfinance arena, certain lacunae in the global MFI system functioning are found omnipresent universally and again Ghana nation cannot be spared in this regard. These short comings also directly or indirectly are also putting stumbling blocks towards candid achievement of the vision of Microfinance: poverty cure

Supply side

- Client identity crisis

The proper client identity crisis in the process of inclusion into microfinance fold is a major hurdle from the financial inclusion perspective in rural areas as it leads to mission drift. Most of the Microfinance institutions in the world reported inclusion of non poor incidentally or intentionally defeating the very purpose of financial inclusion of poor who remain hitherto excluded. According to R. Rosenberg (2004) 91\% of MFIs do not deal with Microfinance activities. While non poor appear taking lions share, even the so called included poor is only served with micro credit tied with the kind of lender and debtor relationship driven by business criteria 'margin' or 'profit' criteria more facilitating the Microfinance institutions, donors and investors globally. Ironically, this sordid situation where the social mission of poverty cure is ignored or sidelined, prevails unnoticed and unchecked. Empirical evidence of shifting the financial service from very poor to less poor or non poor in Ghana (Joseph Kimos Adjei and Thankom Arun. Jan 2009) as detailed in box 1

\section{Box.1 Case study-Sinapi Aba Trust-MFI in Ghana}

The study conducted by Joseph Kimos Adjei and Thankom Arun in 2009 examines the type of people served by one of the leading microfinance institution in Ghana viz., Sinapi Aba Trust(SAT).By comparing the living standard of clients of SAT with non clients representing the general population in its operation area, the study concludes the MFI reaches disproportionately a smaller percentage of very poor people.

The programme plays a key role in determining the type of clients reached by SAT since all located in Urban centre. Shifting financial services from very poor HHs to the less poor.

Source; Microfinance Gate way.org. 'Microfinance and the poor; Whom are they reaching Evidence from Ghana. 'Brooks world poverty Institute. BWPI working paper 72 January 2009

1975. But subsequently from viability perspectives (Praksh Kumar) within the service area, the official committee advocated that the RRBs must be allowed to finance the project of 
non-target groups after meeting the credit needs of target groups. Although Kelkar Committee (1986) did not favor the idea of RRBs financing non-target groups but recommended to lend to those public bodies established for the benefit and welfare of weaker sections. Presently, RRBs in India focus more on non poor clients in urban areas much against the original vision and mission when started, towards uplifting the poor in rural areas. Eventually, the deserving bottom poor in the poverty pyramid remains excluded principally due to absence of a clear cut norms for inclusion of deserving poor clients to be followed scrupulously by the provider of MF for social banking with a mission as already referred

All the facts referred to above amply advocate that the noble vision shift, among the so called institutions which have emerged as saviors of the poor, poses a major threat towards challenging the poverty and unemployment issues through institutionalized microfinance elsewhere..

- Capability differential among the poor client \& ill-suited one size product

Poverty is multifaceted and human beings are diverse in their capabilities. Both these factors remain non transparent but vehemently influence the functioning of the means (like micro credit) in the process of poverty cure. In the poverty pyramid, there are poor who are capable for running micor enterprises, may require micro credit only, With in the same poverty segment there are poorer and the poorest at the bottom who may demand micro credit plus services like capacity building and other welfare goods for their survival. In this context, the MF product based on one size fits for all' formula, regardless of specific need and capability in the poverty pyramid, remains a major threat in the process of poverty cure sustainably in Ghana

\section{- poor Clint protection for the poor}

Another hurdle for inclusive financial inclusion of the poor is Poor clients protection for the poor clients after the sanction of loans. In the context of provision of financial assistance, a mere sanctioning of micro credit is not adequate gesture towards poverty cure. Such provision of microfinance products and services to the poor income people is not the end of the story. These customers should have feel safe while dealing with microfinance institutions and should feel that MFIs are helping them to improve their life not making their life nightmares. The maintenance of debtor -lender relationship without client projection measures to the MF clients as it is practiced for the rich clients is also considered bottlenecks towards achieving the goal of poverty reduction through microfinance sustainably.

\section{Suggestions for a Way Forward}

\section{Institutional linkages}

Microfinance has to play its main role as a panacea for the poor who are by and large found in informal sector with varying demographic characteristics and capabilities. In this context innovative institutional linkages between the formal financial institutions like the commercial Banks regulated by Bank of Ghana and the institutions concerned with microfinance in semi formal (credit unions) and informal sectors (susu clubs) (Figure 2). Linkage banking facilitatesconduiting microfinance from formal institution to the semi/non formal institutions for outreaching the ultimate poor beneficiaries in the last mile. In the context of insignificant outreach of bankfinance through their formal network of offices (Table 2) to the rural 
beneficiaries, the institutional linkage strategy may go a long way for facilitating microfinance institutions both for market deepening and penetration in rural areas. The experience in linkage banking in South and South east Asian countries have amply demonstrate the successful reach of unreached (Rengarajan, 2001) This intuitional linkage banking can be illustrated as follows

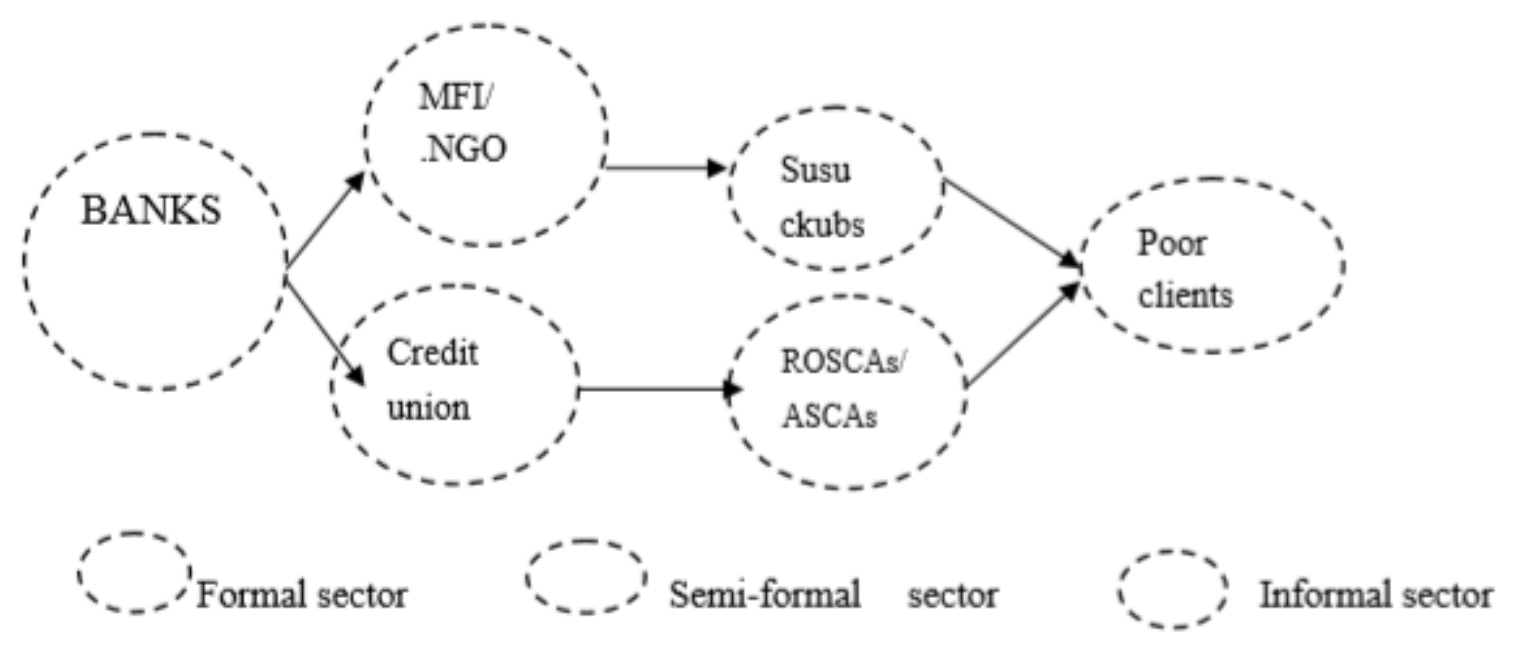

Figure 3. Institutional linkages

In Ghana there is an imperative need for establishment of Linkage of banks with semi formal $\&$ informal players like credit union, susu clubs, The commercial banking system, which has about twenty-three (23) major banks, reaches only about $5 \%$ of households and captures $40 \%$ of money supply]. For example, Barclays, Bank of Ghana (BoG) Ltd launched a micro banking scheme in December 2005 which establishes a formal link between modern finance and susu (one of Africa's most ancient forms of banking) collection in an unconventional mobile initiative across the country Therefore there is room for expanding the microfinance sector in Ghana (Johnson, 2007).

Identification of target group and based on capability differentials

From Microfinance mission perspectives It is a pre requisite not to use genericword for the target group as 'the poor' and to avoid 'one size fits for all 'product. There should be ethically based norm to be adhered for prudently identifying different categories of the poor within the poverty segment such as poor, poorer, the poorest in three different layer in the poverty pyramid and plan for integrated MF products \& services for their respective potential inputs ( financial and non financial) matching to one's capability of the poor clients. For example the poor in the top layer in the poverty pyramid, may need micro credit only since they posses other wherewithal for running micro enterprises while the poorer in the middle layer may demand credit plus services like capability building. The priority demand for bottom poorest is welfare goods (food health care etc) for their immediate survival added with capability building. For the bottom layer micro credit need not be provided at first priority need as it makes them only a mere debtor driving them into debt stress. In this regard, the official 
criteria, mandated for the said purpose may be scrupulously followed.. Alternatively, at micro level, Participatory Wealth Ranking (PWR) exercise may be useful to identify the candid status of each one of the local households in terms of wealth indicators like house structure, productive assets, household asset, food security, income, education, and other social contingencyetc

\subsection{Client Protection}

Poor clients in the informal sector lack financial literacy and digital literacy as well. A creation of kind of modern ombudsman exclusively for helping and guiding MF poor clients is the need of hour in every MFIs. The MFIs /NGOs need to create a customer service cell for providing needed services to the poor clients both for inclusion and after inclusion for ensuring productive utilization of microfinance. Most importantly the clients should not get dropped out after financial inclusion. For the said purpose, susu collectors may be nurtured and trained in client protection methods including digital/mobile services (Table 3). Unless adequate preparedness for imparting digital literacy is arranged for the benefit of informal sector clients, digital divide is imminent and it causes further widening inequity gap.

In regard to client protection to MF clients, it merits mention on 'Smart Campaign' agency who have developed ethically based client protection principles. The Smart Campaign works globally to create an environment in which financial services are delivered safely and responsibly to low-income clients. GHAMFIN. Reserve bank of India and Reserve Bank of Zimbabwe have already taken initiatives in this regard (Rengarajan, 2013). In Nicaragua Banex MFI runs an ombudsman for supporting MF clients.

More particularly, It is important that in the process of graduation of the poor from bottom layer to another one at higher level in the pyramid, client protection through consultancy and other necessary guidance on financial transactions need to be ensured for ensuring protected livelihood tothem and sustainable poverty reduction in developing countries like Ghana

\subsubsection{Capacity Building -Financial Literacy Campaign \& Skill Upgrading}

Financial input (micro credit) alone cannot fetch desired result towards reduction in poverty and unemployment unless the efforts for capability building of both the institutions and the poor clients with two vital non financial components viz., Financial literacy and skill upgrading are seriously considered. For the said task following the identified institutions and their task with accountability are suggested in Table 3.

Table 3. Mentor wise target group and capacity building programme

\begin{tabular}{llll}
\hline Mentor & Target group & Capacity building - core contents \\
\hline Government of Ghana & $\begin{array}{l}\text { Board members } \\
\text { institutions }\end{array}$ & Microfinance & $\begin{array}{l}\text { Skill up graduation and certificate course on } \\
\text { microfinance }\end{array}$ \\
Bank of Ghana & $\begin{array}{l}\text { Board members } \\
\text { institutions }\end{array}$ & Microfinance & $\begin{array}{l}\text { Skill up graduation and certificate course on } \\
\text { microfinance }\end{array}$ \\
Charted institute of & $\begin{array}{l}\text { Board members } \\
\text { Bnstitutions }\end{array}$ & Microfinance & $\begin{array}{l}\text { Financial literacy and certificate course on } \\
\text { microfinance }\end{array}$ \\
\hline
\end{tabular}


Members of this network

From sub sector of microfinance ( credit unions, Susu clubs, Rural community banks, Microfinance companies, savings and loan companies, Financial NGOs, Money lenders)

GHAMFIN

MFI/NGO/SUSU clubs

Mobile companies

GHAMFIN

MFI/NGO/SUSU clubs

Smart Campaign

Source; Compiled by authors

\subsubsection{Provision of Pro Poor Integrated MF Products and Services}

The poverty in Asian and African countries is multifaceted and the poor has to challenge both social vulnerability and economic deprivation which are inextricably mingled within their livelihood. Where as in the case the poor in developed countries, they face income deprivation and are called low income people. It is therefore to provide to the former clients with Micro finance package or integrated MF products and services viz., micro credit plus savings, insurance, leasing, transfer services, capacity building \& customer protection etc while micro credit alone is considered for the latter clients

Although diversified MF products are available in developing countries like Ghana as reviewed earlier, they are made accessible to the poor in a sequestered manner by MFI/NGO/SUSU clubs to the poor clients but not as an integrated manner to the same cohort in the poverty pyramid. Further it is ironical to observe that micro credit alone in the name of microfinance is indiscriminately pumped into the poverty segment there by overheating household economy without any credit discipline: this sordid phenomenon is universally present in the global microfinance arena including Ghana

MFI /NGOs in Ghana need to ensure that integrated MF products and services are provided to the poor clients according to the needs in the respective layer in the poverty pyramid in coordination with the respective institutions that provides MF products like micro insurance. Micro savings, micro leasing etc.

Micro pension. Although the pension scheme has been introduced by National Pension Regulatory Authority in Ghana as already briefed earlier, it remains more generic covering all the workers in both private and public institutions in organized sector. Where as in the case of Indiamicro pension scheme has been identified as one of the vital microfinance product for the poor. Named as Swavalamban Scheme, a co-contributory Pension Scheme, launched in September, 2010 to encourage people from the unorganized sector to voluntarily save for their retirement (Department of Financial services Government of India). The Central Government would contribute a sum of Rs. 1,000 in each National Pension System (NPS) 
account opened under the Scheme where the subscriber is able to save Rs.1000 to Rs. 12000 during a financial year. The Government's contribution is available up to Financial Year 2016-17. The scheme is for those citizens of India who are not part of any statutory pension/provident scheme. The target beneficiaries of Swavalamban Scheme are co-contributory scheme beneficiaries of State Governments, Aanganwaadi workers, Construction workers, Occupational classes like weavers, fishermen, farmers, dairy workers etc. The Scheme is managed by Pension Fund Regulatory \& Development Authority (PFRDA) and financed through budgetary support by way of Grants-in- Aid to PFRDA. The Scheme operates through 62 Aggregators and 71 Point of Presence (PoP). This scheme subsequently changed as Atal Pension Yojana in May 2015.

Government of Ghana and Bank of Ghana may consider introduction of the micro pension scheme for the Microfinance clients in Ghana through Susu collectors as promoting institutions of micro pension or as the agents and also for promoting micro insurance along with their mandatory savings services to the poor clints in coordination with respective government/insurance authority. This strategy will go a long way for outreaching the poor with the micro finance package (micro saving, micro insurance, micro pension) that helps the poor to lead risk free livelihood on one hand and additional income for the Susu collectors on the other.

\section{High Interest Rate and Loan Delinquency}

If one look at modern living from ethical perspectives, it is discernible that we have enough wealth to fulfill our needs but not enough to fulfill our greed. The two phenomenon viz., high interest rate and loan delinquency which are inter related prevailsuniversally in micro finance market. So also it is found inevitably in Ghana.' The contributory factor for this situation is that in the supply side of Micro finance market which emerged as champion for the cause of the poor, greed prevails over honesty in multiple lending practices leading to problems of 'moral hazards' and 'adverse selection' originating from unethical competition and profit motivation in the free market economy with the eventualities such as exclusion, drop outs on one hand multiple borrowing, debt stress, suicides, in the demand side 'on the hand (Rengarajan, 2013).

Following strategies may be considered for challenging these formidable hurdles concerned with interest and repayment of loan

- Moral suasion-, GHAMFIN may influence the MFIs and the poor clients as well in semi and informal sectors by moral suasion to strictly adhear socially acceptable rate of interest or the rate stipulated by GOB and monitor the same.

- In the context of introduction of digitalization in microfinance sector, credit monitoring bureau may be established by GHAMIN for monitoring the credit worthiness of the MF clients who borrowed from multiple sources in informal sector as this would facilitate lending institution to access the credit outstanding status of the of the prospective clients before scrutinizing their loan application. This system helps them for avoiding duplicate financing and multiple financing to the same borrower as well.

- Repayment of dues may be tied up with the marketing of the products of the respective micro enterprises. Ghana Government authorities and corporate bodies under corporate social 
responsibility (CSR) may arrange market avenues/shanties/exhibition for marketing of the products that are produced by the micro enterprises financed by MFIs

- Depending on the nature of micro enterprises and their past repayment behavior, repayment holidays may be considered for their rejuvenation of small and micro enterprises (SMEs) from the temporary period of downfall.

\subsection{Conclusion}

Achieving the social mission through microfinance towards reduction of poverty and unemployment, is not a distress free task; because it depends on the degree of resilience in the demand side that enables the poor to graduate above poverty line in the given forces of political and economic, socio cultural and technological system contextually.

In fine social science axioms indicate that inclusive growth with social change, impacted by higher level of well-being is not static but dynamic in the given ecology and therefore there is a need for consistent replacement of due diligence with the updated one towards ensuring sustainability of what we gained in the social front. From social science perspectives, it is discernible that Microfinance has emerged principally for a social cause for which the present paper codifies prudentially at surface level the bottle necks that hinder the smooth functioning of microfinance towards reduction in poverty and unemployment and make suggestive remedial measures to go forward in Ghana. However, from the perspective of future sustainable development of the poor, it is advocated to conduct a comprehensive study on the structure of various financial intuitions and their MF products and services more intensively and on their impact on the livelihood of the poor in different layers in the poverty pyramid as well, supported empirically with primary data collection at household level. It is surmised that the output of such study would certainly help MFIs to realize desired outcome in the areas which include 'inclusive financial inclusion', designing pro poor integrated MF product and services, ethically nurtured human behavior of the actors in MF industry. This stated social reengineering process in MF sector ultimately would facilitate the task of sustainable reduction of poverty and unemployment in no uncertain terms in Ghana.

\section{References}

Adams, D. W., \& Von Pisehike, J. D. (1992). Microentreprise credit programme, déjà vu. Economics and sociology world Development, 20(10), 1463-1470. https://doi.org/10.1016/0305-750X(92)90066-5

Ali Saleh Ali Alshebami. (2017). The role of microfinance in mitigating poverty and unemployment in Yemen. Ph D thesis in Management science. SRTM University, Nanded, Maharashtra state India.

Alliance for Financial Inclusion. (2018). Digital transformation of microfinance and digitization of microfinance service to deepen financial inclusion in Africa. Alliance for financial inclusion (AFI) 2018.

Aryeetey, E. (2008). Analytical perspectives on stability, growth and poverty. University of Ghana at Legon, Ravi Karbur, Carnel University. Boydel \& Brewel.

Ayeh, R. (2015). Will my micro finance company collapse? Retrieved from www.linkedin.com/pulse/my microfinance -company-collapse-roderick-ayeh

Belaye, F. (2011). Achieving financial inclusion through appropriate regulatory policy. The 
case of Ghana's informal and semi formal institutions.

Boateng, A. A., \& Boateng, G. O. (2014). Assessment of the effectiveness of Ghana microfinance institutions in promoting entrepreneurs in Accra metropolis. Research Journal of Finance and Accounting, 5(6), 15-22.

Bureau et al. (2012). The macroeconomics of microfinance. National Bureau of Economics Research, working paper 17905.

Dahir, A. M. (2015). The challenges facing Microfinance institutions in poverty eradication; a Case study in Mogadishu. International journal of humanities social sciences and education (IJHSSE), 2(2), 56-62.

Government of Ghana. (2017). Budget Statement 2017. Presented in Parliament, Accra, Ghana.

Government of Ghana. (2018). Budget Statement 2018. Presented in Parliament, Accra, Ghana.

Government of Ghana. (November, 2019). The 2019 Budget statement and Economic policy of the Government of Ghana. Presented to Parliament, Accra, Ghana.

Hulme, D., \& Mosley, P. (1996). Finance Against Poverty (volumes 1 and 2). London: Routledge.

Hurissa, R. (2011 December 22). Achievement and challenges of Microfinance institutions in Ethiopia. The case study of Addis Ababa Ethiopia.

ITU. (2014). International telecommunication Union' measuring the international society.

Johnson, A. P., \& Osei, V. (2007). Microfinance in Ghana: An overview. Research Department, Bank of Ghana.

Joseph, K. A., \& Thankom, A. (Jan 2009). Micro finance and the poor; Whom are they reaching .Evidence from Ghana', Brooks world poverty institute BWPI working paper 72

Littlefield, E., Murduch, J., \& Hashemi, S. (2005). Is microfinance an effective strategy to reach the millennium development goals? Focus note series No 24. CGAP-Consultative Group to Assisthr poor, Washington D.C.

Littlefield, E., Murduch, J., \& Hashemi, S. (2003). Is Microfinance an Effective Strategy to Reach the Millennium Development Goals? Focus Note Series no. 24. Washington: CGAP -Consultative Group to Assist the Poor.

Navajos. (2002). Micro credit and the poorest of the poor. Theory and evidence from Bolivia. World Development, 28(2), 333-346

Otero, M. (1999). The evolution of nongovernmental organization towards financial intermediation. Kumerian Press West Hartford, CT.

Rengarajan. (2001). Microfinance technology for poverty alleviation, Paper presented in the Bank economists' conference held in New Delhi India Jan 2001

Rengarajan. (2018). Mystical inclusion; Surgical strikes for inclusive inclusion. Notion press .com Chennai India.

Rengarajan, V. (April 2013 p.8 \& p. 157) Microfinance Principles and Approaches. Tem commandments for responsible financing to the poor Chennai India Notionpress.com 


\section{Macrothink}

Robinson, M. (2001). The microfinance revolution: Sustainable finance for the poor. Washington, DC, World Bank. https://doi.org/10.1596/0-8213-4524-9

Roodman, D. (2011). Due diligence, an impediment enquiring into microfinance. In A. Barrientos, \& D. Hulmes (Eds.), Social protection for the poor and the poorest concept, policies and politics (pp. 315-330). Hamshire, UK. PalgoveMacmillan.

Rosenberg, R. (2004). Microfinance Gate Way 'Sustainability of MFI.

Simanowitz \& Brody (2004). Realizing the potential of microfinance, id21 insights, December, Issue -51.

United Nations Concept Paper. (2005). Building inclusive financial sectors to achieve the millennium development goals (International year of micro credit). United Nations, NY.

Wampah, H. A. K. (2002). Monetary policy framework in Ghana: Practice and challenges. A Paper presented at the International Conference on Monetary Policy frameworks in Developing countries. Organized by the National Bank of Rwanda in collaboration with the IMF, WB and IGC, Kigali.

\section{Copyright Disclaimer}

Copyright for this article is retained by the author(s), with first publication rights granted to the journal.

This is an open-access article distributed under the terms and conditions of the Creative Commons Attribution license (http://creativecommons.org/licenses/by/3.0/). 